\title{
The validity of cross-validation usage in generating digital relief model of
}

\author{
an anthropogenically transformed area
}

\author{
Roksana Zarychta \\ Department of Geomorphology, Faculty of Earth Sciences, University of Silesia, Będzińska Str. 60, 41-200 Sosnowiec, Poland \\ E-mail address: roxana_z@vp.pl
}

\begin{abstract}
Digital relief models deliver a valuable information about the morphology of a particular area. They are useful in structural geomorphology analysis. However, their correct generation requires knowledge of geostatistic methods, including crossvalidation. This article presents the importance of cross-validation, using the example of the Grodziec area (Silesian Upland, southern Poland). The choice of the test area was determined by its geomorphology - high altitude differences (140 meters maximum) and the co-occurence of landforms of different rank, genesis and size. This area includes some towering hills monadnocks, which are Middle-Triassic cuesta remainders. These forms clearly dominate in the surrounding area incised by river valleys. Besides the large forms sculptured by erosion and denudation processes, there are also anthropogenic landforms - stone pits - of much smaller size. We asked the question whether and to what extent they will be "visible" on digital relief models depending on the variogram model setup. Two digital relief models were generated (one with a deliberately incorrect and one with the correct variogram setup) and verified using the cross-validation method. The results of this experiment show that correct digital model carries only slight overestimation of mean squared standardized error while the incorrect model shows substantial underestimation of sampling points values. The correct model is more vivid - it clearly shows most of the relief details while the DTM (digital terrain model) generated by the incorrect setup is misrepresented and blurred. This indicates that conclusions based on incorrect relief models may be subject to high errors.
\end{abstract}

KEY WORDS: geostatistics, cross-validation, Surfer, anthropogenic landforms, Silesian Upland

\section{Introduction}

Digital terrain models present the Earth surface morphology and give information on the local altitudes within the area (GOTLIB ET AL., 2007). While generating the model it is important to be familiar with geostatistic methods as they allow to create precise visualizations of relief which can be used in structural geomorphology. This article's objective is to prove the legitimacy of crossvalidation usage in generating digital terrain models.

For the test area the surroundings of Grodziec have been chosen. The area lies within the administrative district of Będzin, Silesia voivodeship, southern Poland. According to physical and geographical division of Poland (KoNDRACKI, 2000), Grodziec is located in Katowice Upland which is a part of the Silesian Upland (Fig. 1).
The choice of the test area was determined by its geomorphology - high altitude differences (up to 140 meters) and co-occurence of various landforms of different genesis and size. This area includes some towering hills - Middle-Triassic cuesta remainders (monadnocks) - called "mountains". These forms clearly dominate in the surrounding area incised by valleys of rivers Przemsza, Psarka, and Wielonka. The foot of those hills was formed in upper Carboniferous while their upper parts are built of carbonate Triassic rocks, which are more resistant to erosion. The dominating hill is the St. Dorothy Mountain - $381.3 \mathrm{~m}$ above sea level, other hills are of smaller heights - Parcina Mountain 354.4 m a.s.l., and Kijowa Mountain - 345.5 m a.s.l. Besides these large forms sculptured by erosion and denudation processes, there are also anthropogenic landforms, of much smaller sizes. 
Those are stone pits of carbonate rock and coal exploitation, old military trenches, edges of agricultural terraces, incised roads. There is a relatively vast and deep excavation "Rozkówka" in the Western part of the area. It presents a remnant of filling sand exploitation carried out from late thirties until sixties of the $20^{\text {th }}$ century for the now inactive now coal-mine "Grodziec". Even if some of the smaller anthropogenic forms could have been omitted in general analyses, this excavation should be included in them. The question is then whether and to what extent will it be "visible" on digital terrain models depending on the theoretical variogram setup?

The natural and historical aspects of the tested area have been already described, and its relief has been reconstructed using GIS software (BŁASZCZYK, 1982; CiePIELA, 2003; CZYLOK, 2008; DuliAS, 2012; KRAJNIEWSKI, 2009; NitA \& MYGA-PiĄTEK, 2004; SendeK, 1976; SENDEK \& WiKA, 1992; Zarychta, 2012). This article presents the importance of cross-validation usage in relief visualization.

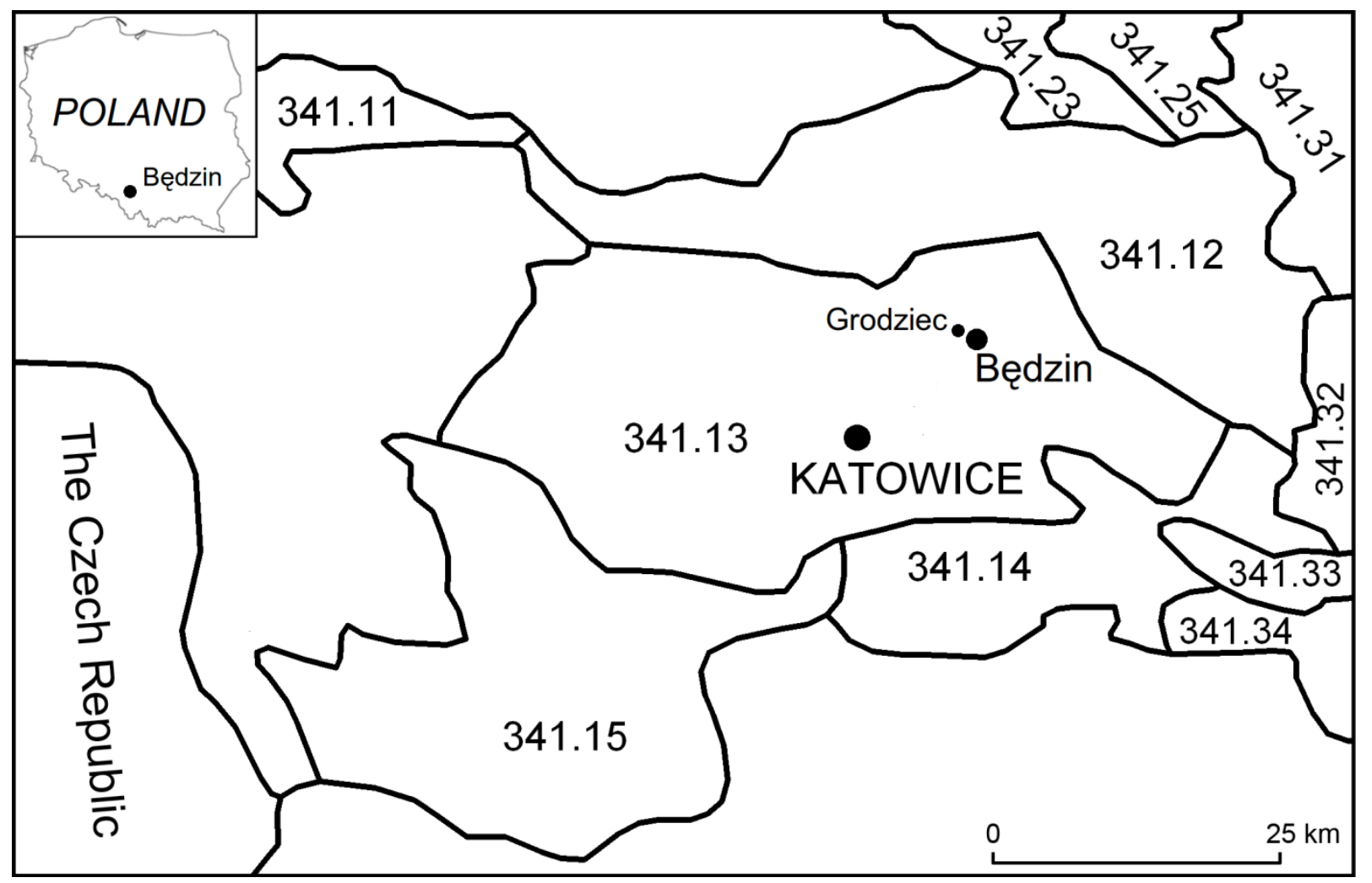

Fig. 1. Location of Grodziec on the background of the geographical regionalization of Poland by Kondracki (2000) 341.11 - Chełm, 341.12 - Tarnowskie Góry Hummock, 341.13 - Katowice Upland, 341.14 - Jaworzno Hills, 341.15 - Rybnik Plateau, 341.23 - Woźniki Ledge, 341.25 - The Valley of Upper Warta, 341. 31 - Częstochowa Upland, 341.32 - Olkusz Upland, 341.33 - Krzeszowice Trench, 341.34 - Tenczyn Hummock

\section{Research experiment}

Prior to the conduction of the experiment, cartographic and remote sensing data analyses have been performed (e.g. TOPOGRAPHIC MAP, 2001; FAUSTMANN, 2006), and a literature query was conducted on the geostatistic methods usage in natural sciences (ARSLAN, 2012; BADURA ET AL., 2012; DAI ET AL., 2011; DAVIS, 2002; KOKESZ, 2006; LIN ET AL., 2002; ŁUPIKASZA, 2007; MATÍAS ET AL., 2004; MUCHA \& WASILEWSKA, 2006; NAMYSŁOWSKAWILCZYŃSKA, 2006; ROUHANI \& MYERS, 1990; STACH, 2009; SZUBERT, 2003, 2007, 2008, 2012; TAVARES ET AL., 2008; USOWICZ ET AL., 2009; WACKERNAGEL, 2003; ZAWADZKI, 2002, 2011).
Geostatistics analyses were performed using Surfer 11 software. They consisted of the application of ordinary (point) kriging along with crossvalidation to visualize the relief of the area near Grodziec. Based on TOPOGRAPHIC MAP (scale 1:10 000, Będzin-Grodziec sheet, 2001), a digital relief model of the area was generated, using the absolute heights. Geostatistic procedure consisted of a few stages, including a structural analysis, cross-validation, gridding were performed with a particular attention paid to cross-validation. As a result of contour lines digitalization 3012 sampling points were received which created a basis for structural analysis (Tab. 1, Fig. 2). 
Table 1. Cartesian coordinates (XY) of 10 selected sampling points along with their height values (Z) within examined area

\begin{tabular}{|c|c|c|}
\hline $\mathrm{X}$ & $\mathrm{Y}$ & $\mathrm{Z}$ \\
\hline 0.081804 & 3.393048 & 250 \\
\hline 0.076234 & 3.394915 & 250 \\
\hline 0.070665 & 3.399574 & 250 \\
\hline 0.071593 & 3.407018 & 250 \\
\hline 0.079947 & 3.407940 & 250 \\
\hline 0.093871 & 3.406994 & 250 \\
\hline 0.097584 & 3.401407 & 250 \\
\hline 0.092943 & 3.393967 & 250 \\
\hline 0.793949 & 0.854148 & 260 \\
\hline 0.777947 & 0.859895 & 260 \\
\hline
\end{tabular}

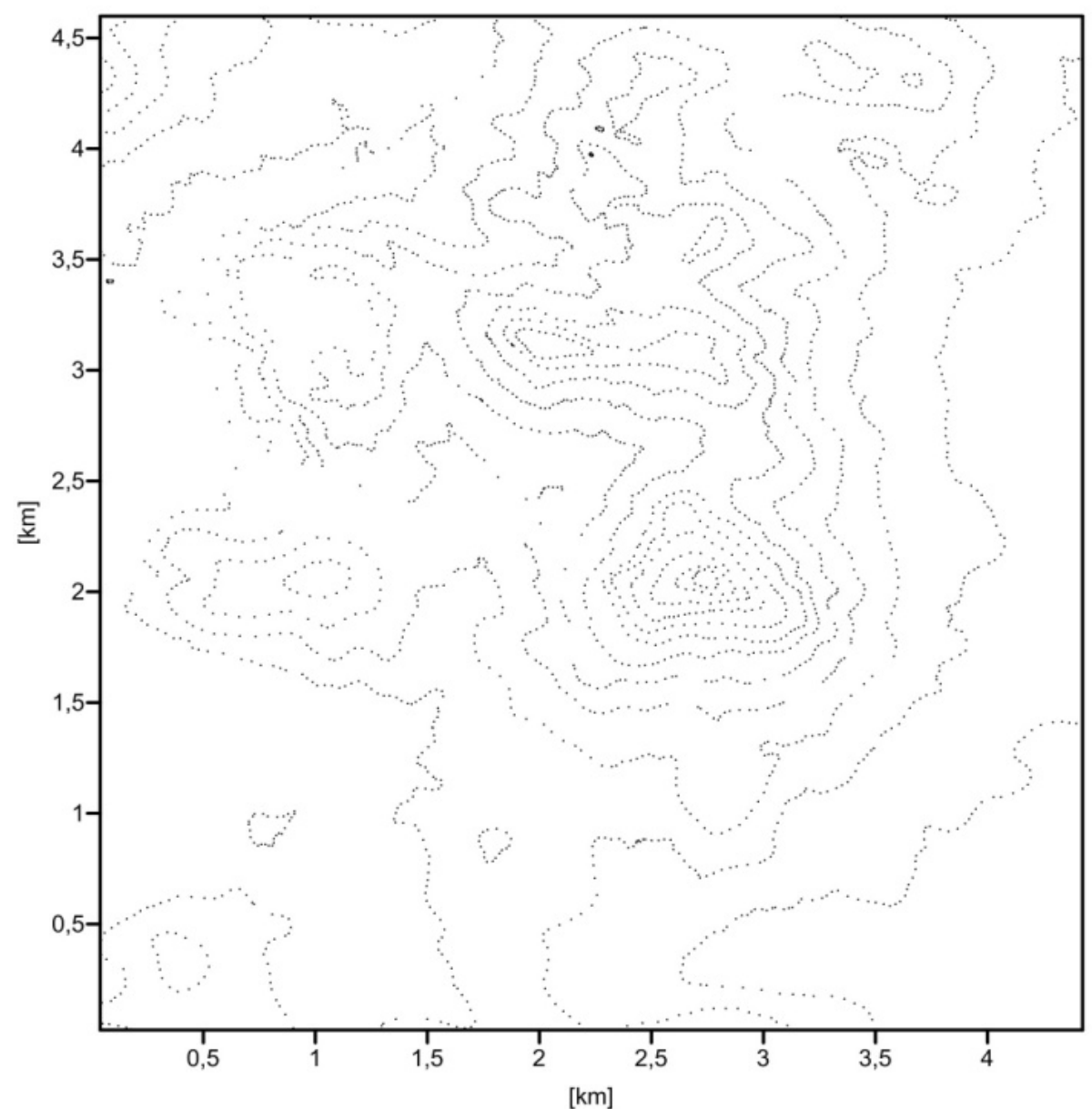

Fig. 2. The distribution of sampling points within the examined area

The essence of structural analysis is the generation of experimental (empirical) variogram preceded by variance calculation based on previously received sampling points values. The generated empirical variogram shows the relationship between variance and the distance between sampling points (MARMOL, 2002) (Tab. 2, Fig. 3).

Table 2. Empirical variogram parameters of Grodziec area

\begin{tabular}{|c|c|c|c|c|c|c|}
\hline Direction & Tolerance & Step Amount & $\begin{array}{c}\text { Max Lag } \\
\text { Distance }\end{array}$ & $\begin{array}{c}\text { Number of } \\
\text { Lags }\end{array}$ & Lag Width & Vertical Scale \\
\hline 0 & 90 & 30 & 2.1 & 25 & 0.084 & 582 \\
\hline
\end{tabular}




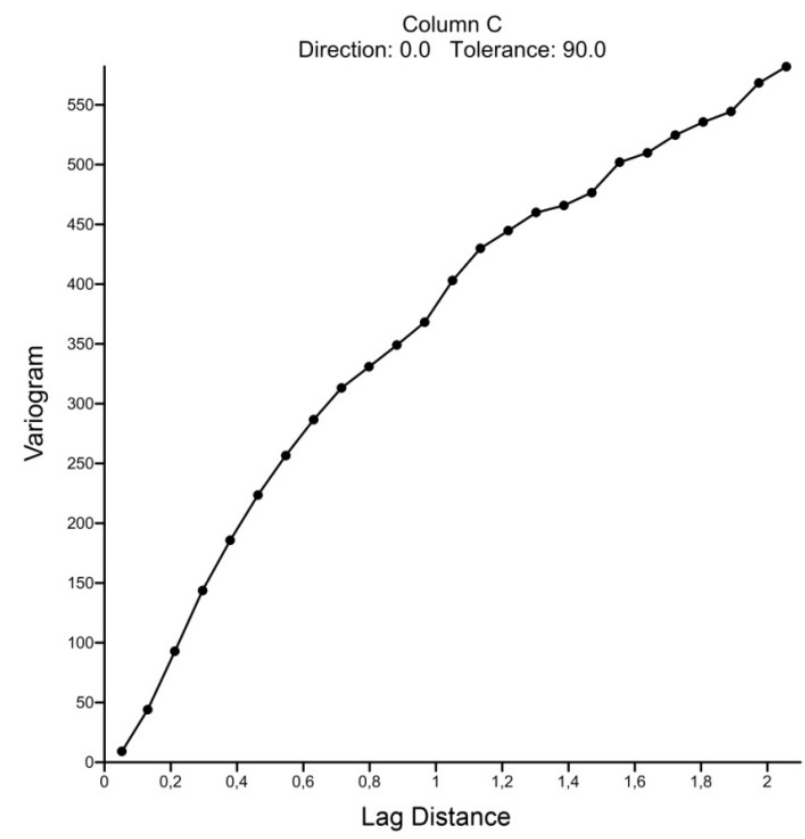

Fig. 3. The empirical variogram of Grodziec area

In order to show the importance of using compared with a deliberately unadjusted theoretical cross-validation in generating digital terrain models, variogram constisting of a "hole-effect" model the obtained experimental variogram has been and a "nugget effect" model (Tab. 3, Fig. 4).

Table 3. Parameters of theoretical models deliberately unadjusted with the empirical variogram

\begin{tabular}{|c|c|c|c|}
\hline \multicolumn{4}{|c|}{ Hole-effect model } \\
\hline \multirow{2}{*}{ Scale } & \multirow{2}{*}{ Lenght (A) } & \multicolumn{2}{|c|}{ Anisotropy } \\
\hline & & Ratio & Angle (degrees) \\
\hline 250 & 0.1 & 1 & 0 \\
\hline \multicolumn{4}{|c|}{ Nugget effect model } \\
\hline \multicolumn{2}{|c|}{ Error variance } & \multicolumn{2}{|c|}{ Micro variance } \\
\hline \multicolumn{2}{|c|}{132} & \multicolumn{2}{|c|}{0} \\
\hline
\end{tabular}

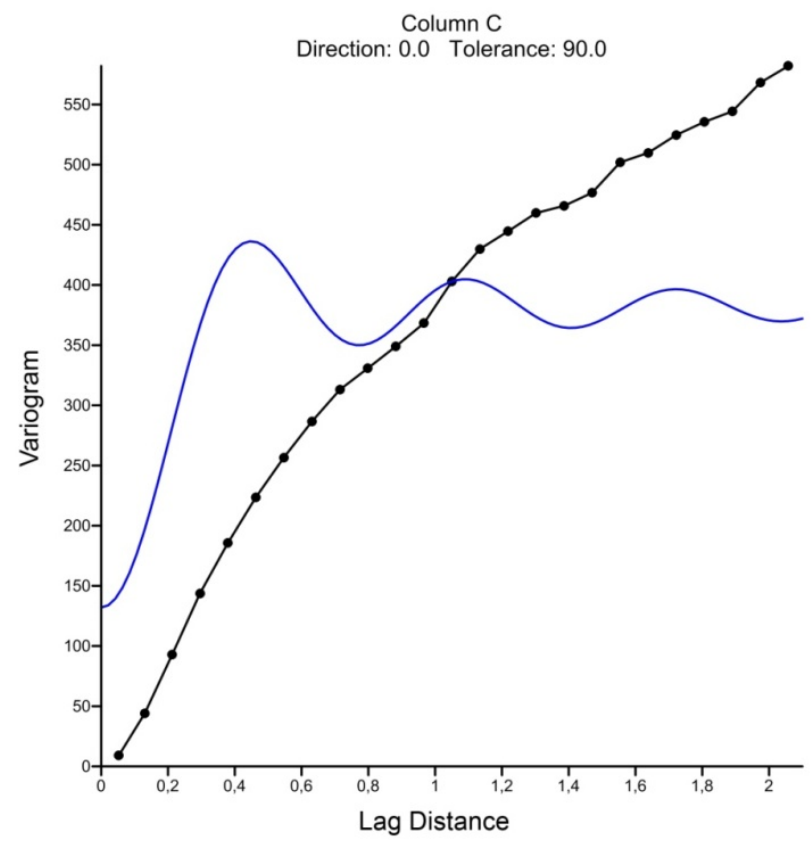

Fig. 4. The empirical variogram along with a „hole-effect” model and a „nugget effect” model, both deliberately unadjusted with it (blue line - theoretical model) 
The next step allowing to verify the correctness of variogram setups was the cross-validation. According to KORONACKI \& ĆWIK (2005), crossvalidation performed $K$ times (where $K$ usually equals 5 or 10) proceeds as follows:

(1) division of the original sample - so- called training dataset - into $K$ equal parts,

(2) generation of various $K$ pseudo-samples from the training dataset (pseudo-samples are being created by removing one of $K$ parts from one original training dataset (where every pseudosample consists of $K-1$ part of the training dataset); the first pseudo-sample is a result of removing the first of $K$ parts from the training dataset, the second pseudo-sample is created as a result of removing the second of $K$ parts from the original dataset, and the rest of pseudo-samples are prepared accordingly,

(3) the construction of a given classifier performed $K$ times (every time based on different pseudosample); as a result of this procedure the $K$ version of the same classifier is being received (the first classifier version based on the first pseudo-sample, the second based on the second pseudo-sample, etc.) while $K$ pseudo-sample is treated as a training dataset for the $K$ version of the classifier,

(4) the verification of $K$ version of a given classifier based on a number of erroneous classifications executed by $K$ version on the original part of the training dataset which did not "enter" the $K$ pseudo-sample,

(5) probability estimation of performing incorrect classification by a given classifier (based on total number of classification errors for all $K$ versions of the classifier divided by $n$ numbers in the original sample); the division result is a fraction of erroneous classifications performed by the given classifier,

(6) the selection of a classifier with the smallest fraction of erroneous classifications,

(7) repeated classifier construction based on the whole training dataset; acquired classifier is the definite solution of the classifying procedure.
There exists also a leave-one-out cross-validation, with $n$ elements of the original training dataset. As a result of eliminating only one observation from the original sample, the pseudo-sample numbering $n-1$ elements is received. Each of the given classifier versions is evaluated based on classification of one observation, therefore the estimation of the following quality versions of the classifier is performed based on observations not involved in its creation. As a result of the estimation of the probability of an erroneous classification can be described as unbiased (KORONACKI \& ĆWIK, 2005).

All sampling points of the analyzed case have been subjected to the leave-one-out cross-validation, using the ordinary (point) kriging method. As a result, the estimated values in sampling points and residuum were received (Tab. 4). The estimation is a procedure of finding the real values in sampling points based on known values of the adjoining points. The estimated values were calculated using the formula:

$$
Z^{*}\left(x_{0}\right)=\sum_{i=1}^{n} w_{i} Z\left(x_{i}\right)
$$

where:

$Z\left(x_{i}\right)$ - real value in the sampling point,

$w_{i}$ - kriging weight (with a fulfilled condition of measurement being unbiased, the sum of ordinary kriging weights equals 1 (vide NAMYSŁOWSKAWILCZYŃSKA, 2006).

Residuum is an estimation error defined by following formula:

$$
R\left(x_{0}\right)=Z^{*}\left(x_{0}\right)-Z\left(x_{0}\right)
$$

where:

$Z^{*}\left(x_{0}\right)$ - estimated value in the sampling point, $Z\left(x_{0}\right)$ - real value in the sampling point.

Table. 4. Parameters of 10 selected sampling points received as a result of cross-validation usage based on incorrect variogram setups

(X,Y - Cartesian coordinates of real points, Z - height value in XY points, $\mathrm{Z}^{*}$ - estimated value, $\mathrm{R}$ - residuum, nData - number of neighbours)

\begin{tabular}{|c|c|c|c|c|c|}
\hline $\mathrm{X}$ & $\mathrm{Y}$ & $\mathrm{Z}$ & $\mathrm{Z}^{*}$ & $\mathrm{R}$ & $\mathrm{n}$ Data \\
\hline 0.081804 & 3.393048 & 250 & 257.8117 & 7.811746 & 51 \\
\hline 0.076234 & 3.394915 & 250 & 257.7382 & 7.738241 & 48 \\
\hline 0.070665 & 3.399574 & 250 & 257.9055 & 7.905473 & 45 \\
\hline 0.071593 & 3.407018 & 250 & 258.8173 & 8.817334 & 46 \\
\hline 0.079947 & 3.407940 & 250 & 259.4347 & 9.434672 & 51 \\
\hline 0.093871 & 3.406994 & 250 & 260.0198 & 10.01980 & 56 \\
\hline 0.097584 & 3.401407 & 250 & 259.6173 & 9.617287 & 56 \\
\hline 0.092943 & 3.393967 & 250 & 258.4462 & 8.446204 & 53 \\
\hline 0.793949 & 0.854148 & 260 & 261.1118 & 1.111811 & 63 \\
\hline 0.777947 & 0.859895 & 260 & 260.5587 & 0.558653 & \\
\hline
\end{tabular}


In order to verify the correctness of the conducted modeling, the following errors were calculated based on the afore-mentioned parameters: mean error (ME), mean squared error (MSE), mean squared standardized error (MSSE) (CICHOCIŃSKI, 2011; Tab. 5).

ME informs about average difference between estimated value and the value measured and its value should be close to zero. It is represented by formula:

$$
\frac{\sum_{i=1}^{n} R\left(x_{i}\right)}{n}
$$

where:

$R\left(x_{i}\right)$ - residuum value of the sampling points $n$ - number of variables

MSE informs about the degree of approximation of the estimated values in comparison with real values. Its value should equal the variance. MSE is represented by formula:

$$
\frac{\sum_{i=1}^{n}\left[R\left(x_{i}\right)\right]^{2}}{n}
$$

MSSE points out under- or overestimation of estimated values in comparison with real values. Its value should be close to 1 (if it is more that 1 the variable has been underestimated, otherwise it has been overestimated). MSEE is represented by formula:

$$
\frac{1}{n} \sum_{i=1}^{n} \frac{\left[R\left(x_{i}\right)\right]^{2}}{\sigma_{i}^{2}}
$$

where:

$\sigma_{i}^{2}-$ kriging variance.

Table. 5. The values of three errors along with the variance received as a result of cross-validation usage based on incorrect variogram setups (error indices are explained in main text)

\begin{tabular}{|c|c|}
\hline Error type & Error value \\
\hline ME & 0.0041 \\
\hline MSE & 4.0578 \\
\hline Variance & 4.0591 \\
\hline MSSE & 2.0144 \\
\hline
\end{tabular}

Based on the received results, it can be stated that a cross-validation procedure did not confirm the match of complex "hole-effect" model with "nugget effect" model in analyzed case. The mean squared standardized error value shows a significant underestimation of the value in comparison to reality. Therefore the repeated setup of theoretical variograms has been performed. The complex model consisted of two spherical models as well as a "nugget effect" model (Tab. 6, Fig. 5). The crossvalidation has shown the estimated values and estimation errors, based on which the mean error, mean squared error, and mean squared standardized error were calculated (Tab. 7, 8).

Table 6. Parameters of different theoretical models repeatedly adjusted with the empirical variogram

\begin{tabular}{|c|c|c|c|c|}
\hline \multicolumn{5}{|c|}{ Spherical models } \\
\cline { 3 - 5 } Model number & \multirow{2}{*}{ Scale } & \multirow{2}{*}{ Lenght (A) } & Ratio & Anisotropy \\
\cline { 3 - 5 } & 50 & 1 & 1 & 0 \\
\hline 1 & 540 & 2.4 & 1 & 0 \\
\hline 2 & \multicolumn{2}{|c|}{ Nugget effect model } \\
\hline \multicolumn{3}{|c|}{ Error variance } & \multicolumn{2}{c}{0} \\
\hline
\end{tabular}

Repeatedly performed cross-validation confirmed the rightness of selection of theoretical variograms used in the complex model. Mean square standardized error and its value which proved only slight overestimation in sampling points played a decisive part in the estimation of the ultimate theoretical model. As a consequence, a gridding procedure with usage of ordinary (point) kriging was performed after performing the cross-validation for both deliberately incorrectly and correctly setup variograms. Hypsometric maps were obtained, based on which the digital terrain models of Grodziec area were generated in order to present the difference between geostatistic analyses - the initial one being erroneous and the final one being correct (Figs. 6-9). 


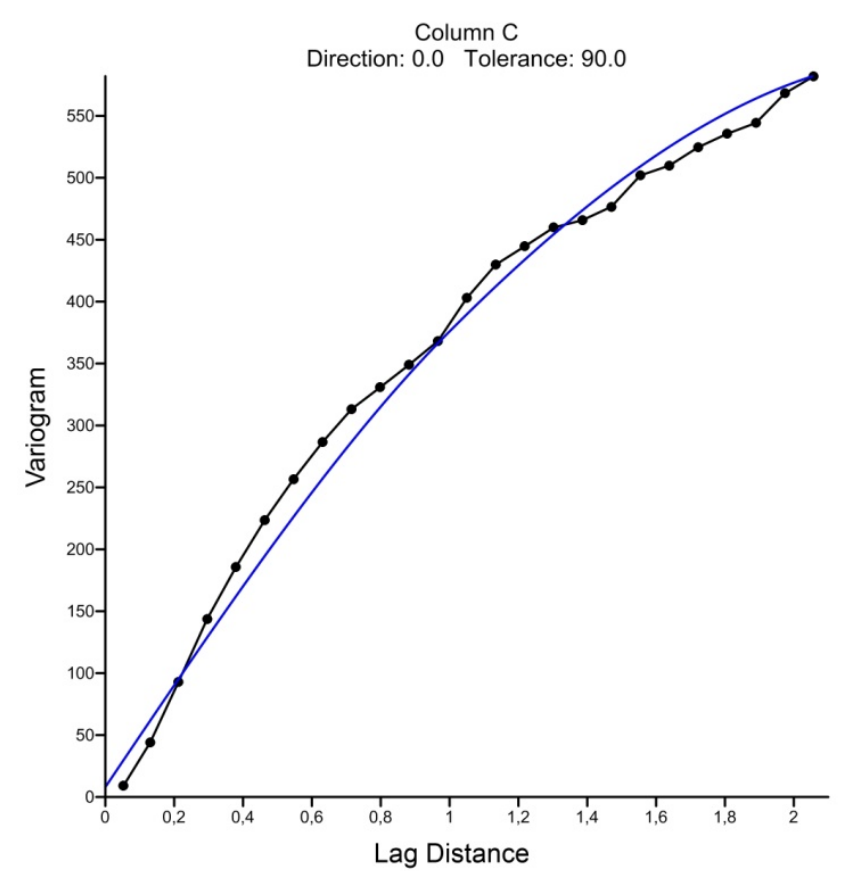

Fig. 5. The empirical variogram and the variogram of combined spherical models and the "nugget effect" model (blue line - combined theoretical models)

Table 7. Parameters of 10 selected sampling points received as a result of cross-validation usage based on repeatedly performed variogram setups

$\left(\mathrm{X}, \mathrm{Y}\right.$ - Cartesian coordinates of real points, $\mathrm{Z}$ - height value in $\mathrm{XY}$ points, $\mathrm{Z}^{*}$ - estimated value, $\mathrm{R}$ - residuum, nData - number of neighbours)

\begin{tabular}{|c|c|c|c|c|c|}
\hline $\mathrm{X}$ & $\mathrm{Y}$ & $\mathrm{Z}$ & $\mathrm{Z}^{*}$ & $\mathrm{R}$ & $\mathrm{nData}$ \\
\hline 0.081804 & 3.393048 & 250 & 249.8002 & -0.199840 & 51 \\
\hline 0.076234 & 3.394915 & 250 & 249.8645 & -0.135470 & 48 \\
\hline 0.070665 & 3.399574 & 250 & 250.4673 & 0.467273 & 45 \\
\hline 0.071593 & 3.407018 & 250 & 251.7555 & 1.755541 & 46 \\
\hline 0.079947 & 3.407940 & 250 & 251.5838 & 1.583753 & 51 \\
\hline 0.093871 & 3.406994 & 250 & 252.6416 & 2.641564 & 56 \\
\hline 0.097584 & 3.401407 & 250 & 252.1324 & 2.132380 & 56 \\
\hline 0.092943 & 3.393967 & 250 & 250.6311 & 0.631147 & 53 \\
\hline 0.793949 & 0.854148 & 260 & 260.2940 & 0.293963 & 63 \\
\hline 0.777947 & 0.859895 & 260 & 259.9329 & -0.067110 & 63 \\
\hline
\end{tabular}

Table 8. Error values received as a result of using cross-validation based on repeatedly performed variogram setups (error indications are explained in main text)

\begin{tabular}{|c|c|}
\hline Error type & Error value \\
\hline ME & 0.0053 \\
\hline MSE & 0.6379 \\
\hline Variance & 0.6381 \\
\hline MSSE & 0.9287 \\
\hline
\end{tabular}

\section{Results}

The generated terrain models are significantly different. The correctly generated digital model is more vivid - the hills St. Dorothy, Parcina, and Kijowa have been clearly shown. The old sandpit "Rozkówka" can also be seen (Fig. 7). Incorrect digital terrain model is more blurred (Fig. 9). The excavation of „Rozkówka” is more difficult to distinguish among other hollow terrain forms shown in the western part of the area. The picture of the relief is falsified as the model shows dents which are non-existent in reality. This indicates that the research conclusions based on an incorrectly prepared terrain model would be prone to large errors. 


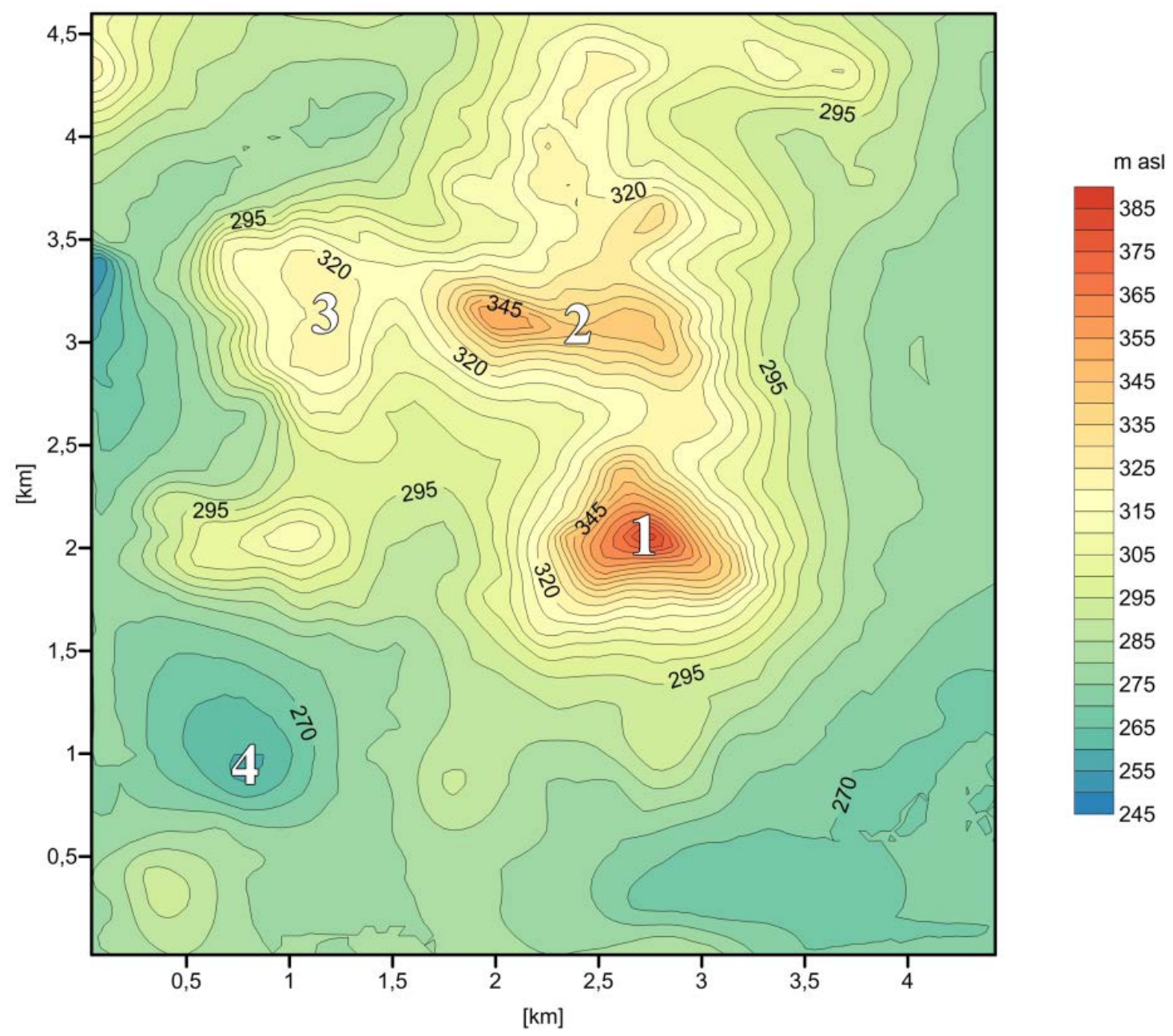

Fig. 6. The correctly generated hypsometric map of area near Grodziec

1 - St Dorothy Mountain, 2 - Parcina Mountain, 3 - Kijowa Moutain, 4 - „Rozkówka” excavation

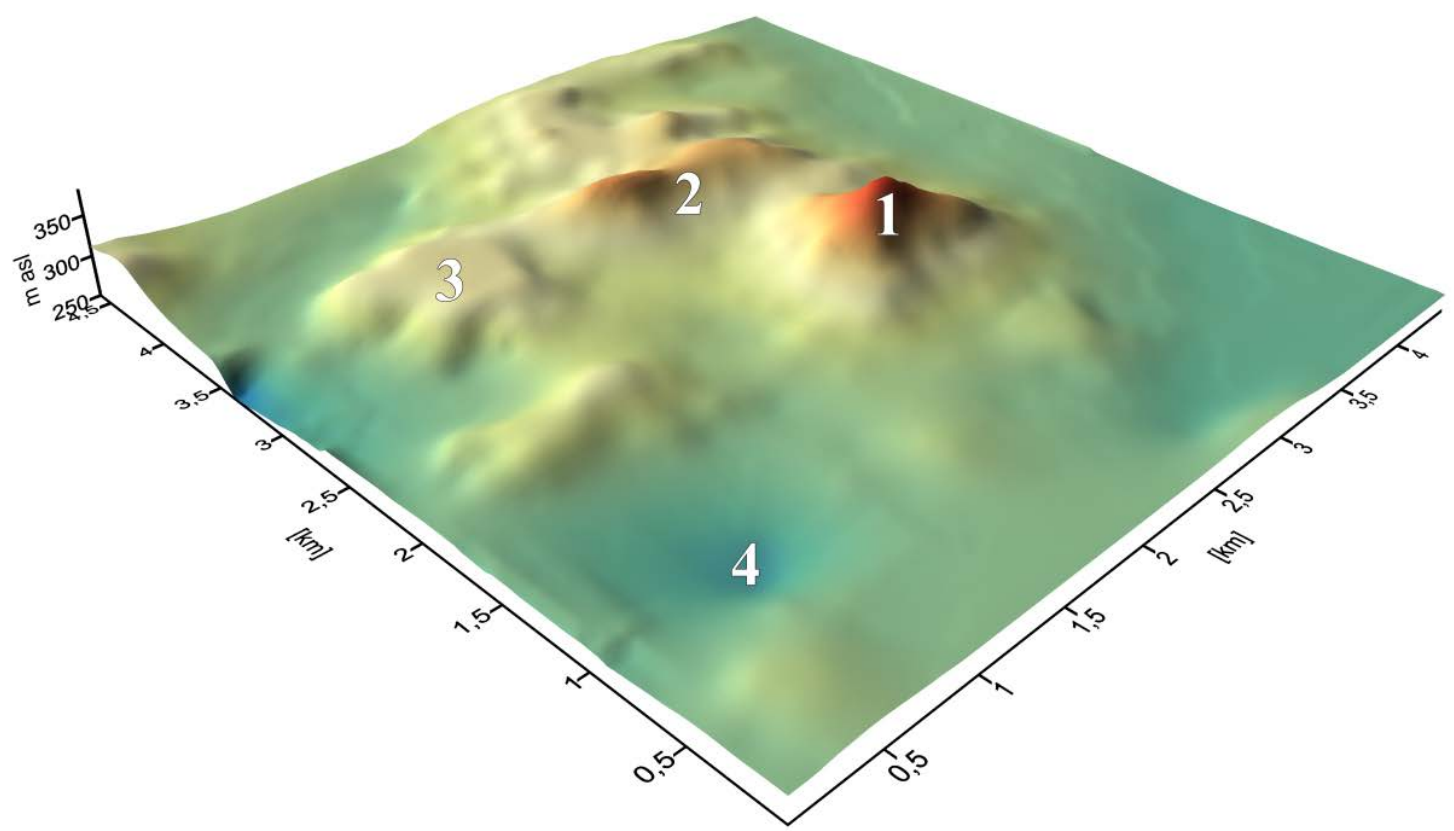

Fig. 7. Correctly generated DTM of area near Grodziec

1 - St Dorothy Mountain, 2 - Parcina Mountain, 3 - Kijowa Moutain, 4 - „Rozkówka” excavation 


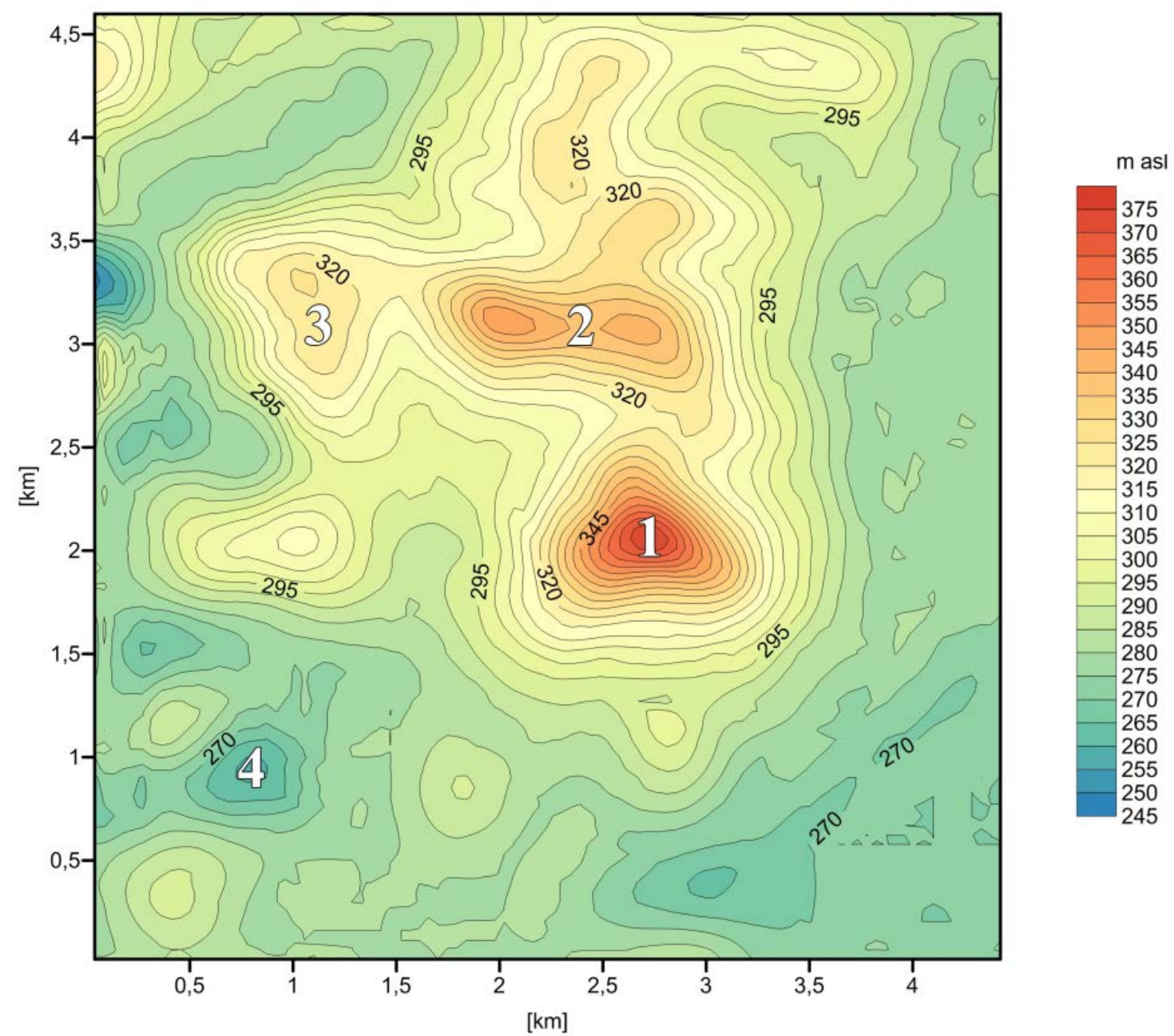

Fig. 8. The incorrectly generated hypsometric map of the area near Grodziec

1 - St Dorothy Mountain, 2 - Parcina Mountain, 3 - Kijowa Moutain, 4 - „Rozkówka” excavation

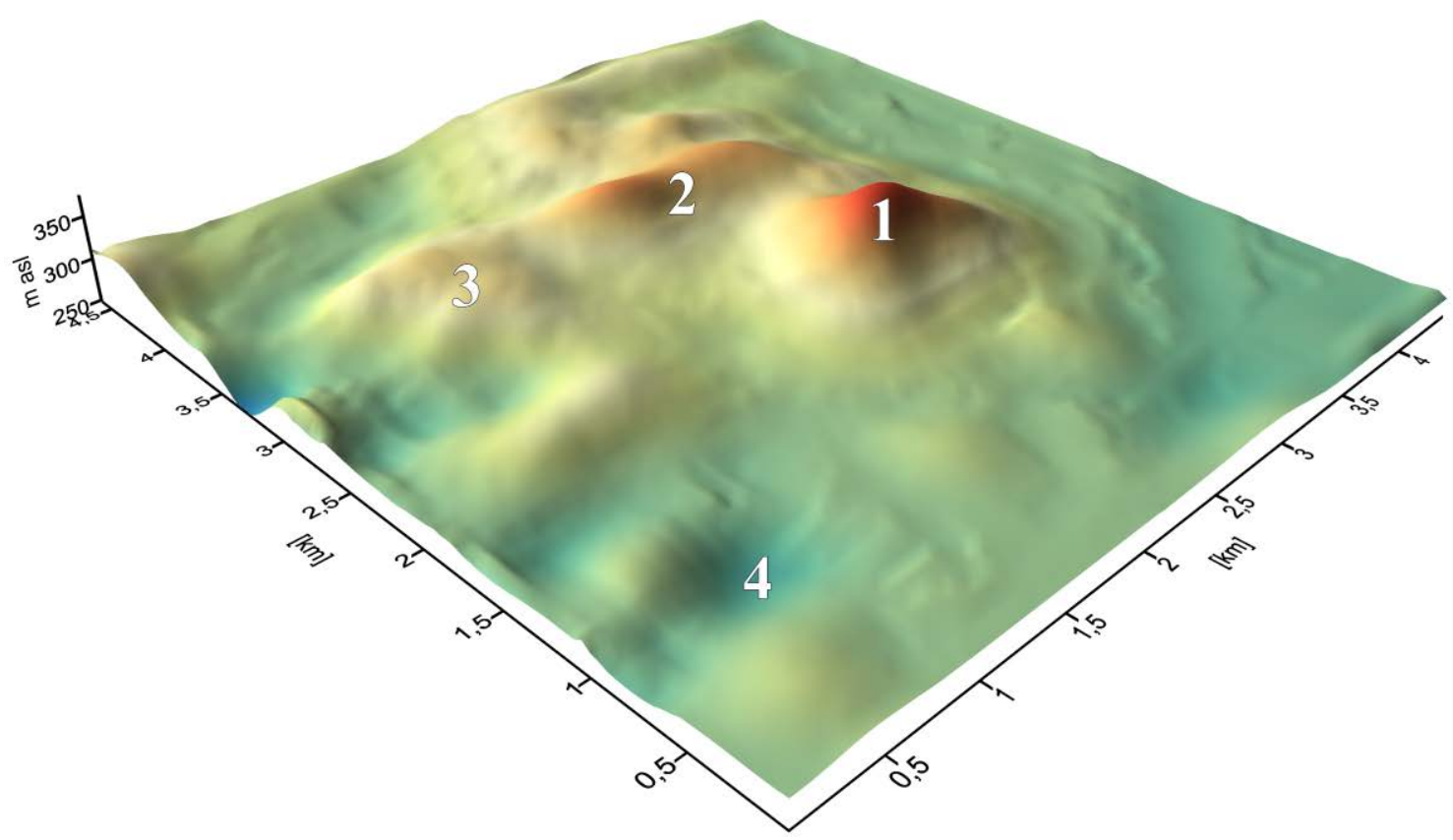

Fig. 9. Incorrectly generated DTM of area near Grodziec

1 - St Dorothy Mountain, 2 - Parcin Mountain, 3 - Kijowa Moutain, 4 - „Rozkówka” excavation 
The results of the test consisting of deliberately incorrect theoretical variograms selection showed how the cross-validation has registered the error. The repeated test with the correct variogram setup (vide ZAWADZKI, 2011) shows a mean square standardized error of slightly overestimated value. It allowed to generate another digital terrain model correctly showing relief details of the analyzed area.

\section{Summary}

What is necessary in order to perform the whole procedure of generating DTM is the knowledge of geostatistic methods usage in natural sciences and an experience in their application. The usage of cross-validation requires numerous calculation steps (depending on the number of the original training dataset), therefore conducting "manual" estimations for analyzed case is "physically" impossible without the adequate software. Nonexperienced scientists however "forget" about the cross-validation confining themselves to assumptive theoretical geostatistic models which are used in kriging (e.g. in Surfer linear model.)

Cross-validation is a part of structural analysis, therefore it is an important tool for choosing the best geostatistical model. Nevertheless if we are obliged to generate a digital terrain model and are not familiar with structural analysis, the acquaintance with potential values of the three afore-mentioned cross-validation errors (particularly the mean square standardized error which shows over- or underestimation of the value in trial points) will suffice. However, the correct generation of digitalal terrain models without the knowledge of geostatistic methods requires time-consuming combinations of adjusting theoretical model(s) to the empirical variogram. By only re-setting crossvalidation using a repeatable procedure, we can achieve satisfying results.

\section{References}

Arslan H. 2012. Spatial and temporal mapping of groundwater salinity using ordinary kriging and indicator kriging: The case of Bafra Plain, Turkey. Agricult. Water Managem., 113: 57-63.

Badura H., Zawadzki J., Fabijańczyk P. 2012. Kriging blokowy oraz metody GIS w geostatystycznym szacowaniu metalonośności w kopalniach węgla kamiennego. Roczn. Geomatyki, X, 3(53): 17-26.

Błaszczyk W. 1982. Będzin przez wieki: dzieje miasta i jego rozwoju urbanistyczno-przestrzennego od średniowiecza do połowy XX w. na podłożu osadnictwa $w$ starożytności $i$ wczesnym średniowieczu. PTTK Oddz. w Będzinie, Poznań: 136-188.

Cichociński P. 2011. Porównanie metod interpolacji przestrzennej w odniesieniu do wartości nieruchomości. Stud. i Mat. Tow. Nauk. Nieruchom., 19(3): 120-131.
Ciepiela B. 2003. Grodziec dawniej i dziś. Zarys rozwoju miejscowości i przemysłu. Progres, Sosnowiec, BędzinGrodziec: 156-220.

Czylok A. 2008. Przyroda ożywiona [in:] Pulinowa M. Z. (ed.) Będzin 1358-2008. Środowisko przyrodniczo-geograficzne, T. 1. Muzeum Zagłębia, Będzin: 128-129.

Dai H., Ren L., Wang M., Xue H. 2011. Water distribution extracted from mining subsidence area using Kriging interpolation algorithm. Transactions of Nonferrous Metals Society of China, 21(3): 723-726.

Davis J. 2002. Statistics and data analysis in geology. John Wiley \& Sons, New York, Chichester, Brisbane, Toronto, Singapore.

Dulias R. 2012. Góra Św. Doroty - świadek przeszłości geologicznej i kulturowej. Acta Geogr. Siles., nr spec. 2: 13-18.

Faustmann D. (ed.) 2006. Mapa turystyczna Zagłębie Dąbrowskie w skali 1:50 000. Compass, Kraków.

Gotlib D., Iwaniak A., Olszewski R. 2007. GIS: obszary zastosowań. Wyd. Nauk. PWN, Warszawa.

Kokesz Z. 2006. Trudności i ograniczenia w geostatystycznym modelowaniu zmienności złóż i szacowaniu zasobów metodą krigingu. Gospod. Sur.Min. 22(3): 5-20.

Kondracki J. 2000. Geografia regionalna Polski. Wyd. Nauk. PWN, Warszawa.

Kornacki J., Ćwik J. 2005. Statystyczne systemy uczące się. Wyd. Nauk.-Techn., Warszawa: 90-91.

Krajniewski J. 2009. Góra Św. Doroty - symbol Zagłębia. [in:] Dodatek do Ziemi Będzińskiej, 10/22.

Lin Y-P., Chang T-K. ,Shih Ch-W., Tseng Ch-H. 2002. Factorial and indicator kriging methods using a geographic information system to delineate spatial variation and pollution sources of soil heavy metals. Environ. Geology, 42(8): 900-909.

Łupikasza E. 2007. Metody analizy przestrzennej w badaniu zmienności opadów w Europie. Roczn. Geomatyki, 5(1): 71-80.

Mapa topograficzna w skali 1:10 000, arkusz Będzin-Grodziec. Główny Geodeta Kraju, OPGK, Rzeszów, 2001.

Marmol U. 2002. Modelowanie reprezentacji powierzchni topograficznej z wykorzystaniem metody geostatystycznej. Geodezja, 8(2): 259-270.

Matías J. M., Vaamonde A., Taboada J., González-Manteiga W. 2004. Comparison of Kriging and Neural Networks With Application to the Exploitation of a Slate Mine. Mathemat. Geology, 36(4): 463-486.

Mucha J., Wasilewska M. 2006. Nieparametryczne geostatystyczne metody interpolacji parametrów wybranych złóż. Przegl. Górn., 62(1): 24-31.

Namysłowska-Wilczyńska B. 2006. Geostatystyka. Teoria $i$ zastosowania. OWPW, Wrocław: 356.

Nita J., Myga-Piątek U. 2004. Application of spatial visualization methods for designing landscape changes on the example of st. Dorothy's hill in Będzin. Geographical Information System in research \& practice, Zagrzeb: 328-336.

Rouhani S., Myers D.E. 1990. Problems in space-time kriging of geohydrological data. Mathemat. Geology, 22(5): 611-623.

Sendek A. 1976. Góra Św. Doroty na Wyżynie Śląskiej. Chrońmy Przyr. Ojcz., 36, 2: 68-71.

Sendek A., Wika S. 1992. W sprawie ochrony Góry Św. Doroty - projekt zespołu przyrodniczo-krajobrazowego. Kształt. środ. geogr. i ochr. przyr. na obsz. uprzem. i zurb., 7: $33-42$.

Stach A. 2009. Analiza i modelowanie struktury przestrzennej. [in]: Zwoliński Z. [ed.] GIS platforma integracyjna geografii. Bogucki Wyd. Nauk, Poznań: 115-143.

Szubert M. 2003. Cyfrowy model wysokości powierzchni podczwartorzędowej na Wyżynie Woźnicko-Wieluńskiej. 
Arch. Fotogram., Kartogr. i Teledet., Mat. Ogólnopol. Symp. Geoinformacji „Geoinformacja zintegrowanym narzędziem badań przestrzennych" Wrocław - Polanica Zdrój, 13 A: 233-242.

Szubert M. 2007. Geoinformatyka w geomorfologii na przykładzie badań geomorfologicznych na Wyżynie Wieluńskiej i Częstochowskiej. Arch. Fotogram., Kartogr. i Teledet., 17b: 759-768.

Szubert M. 2008. Geomatyka w badaniach geomorfologicznych. Dok. Geogr. Fiz., 37: 7-13.

Szubert M. 2012. Plejstoceńska morfogeneza Wyżyny Woźnicko-Wieluńskiej zwiq̨zana ze stadiałem maksymalnym zlodowacenia Odry w świetle geostatystycznej rekonstrukcji powierzchni podplejstoceńskiej. Wyd. Nauk. UP, Kraków.

Tavares M.T., Sousa A.J., Abreu M.M. 2008. Ordinary kriging and indicator kriging in the cartography of trace elements contamination in São Domingos mining site (Alentejo, Portugal). Jour. of Geochem. Explor., Geostat. Applied to Environment. Studies $8^{\text {th }}$ Geochemical Congress of the Portuguese Speaking Countries, 98(1-2): 43-56.
Usowicz B., Marczewski W., Lipiec J., Usowicz J.B., Sokołowska Z., Dąbkowska-Naskręt H., Hajnos M., Łukowski M.I. 2009. Woda w glebie - pomiary naziemne $i$ satelitarne $w$ badaniach zmian klimatu. PAN, Kom. Agrofizyki, Wyd. Nauk. FRNA, Lublin.

Wackernagel H. 2003. Multivariate geostatostics. An introduction with applications. Third, completely revised edition. Springer-Verlag, Heidelberg: 1-387.

Zarychta R. 2012. Wartości przyrodniczo - kulturowe „Zagłębiowskiego Olimpu” [in:] Kuczera M. (ed.) Nowe trendy $w$ naukach przyrodniczych, Tom III. Creative Science - Monografia 2011. Creativetime, Kraków: 170180.

Zawadzki J. 2002. Badania korelacji przestrzennych zawartości wybranych pierwiastków śladowych w glebach Warszawy i okolic. Ochr. Środ., 24 (4): 17-26.

Zawadzki J. 2011. Metody geostatystyczne dla kierunków przyrodniczych i technicznych. Oficyna Wyd. Politech. Warsz., Warszawa. 